Pro-Fil (Special Issue) 2021: 18-22

https://doi.org/10.5817/pf21-3-2397

\title{
VESMÍR, LIDÉ A VIRY (STANISŁAW LEM)
}

\author{
PETR JEMELKA \\ Katedra občanské výchovy, Pedagogická fakulta Masarykovy univerzity, \\ Brno, Česká republika, jemelka@ped.muni.cz \\ PƯVODNÍ VĚDECKÁ PRÁCE • OBDRŽENO: 14/9/2021 • PŘIJATO: 20/10/2021
}

\begin{abstract}
Abstrakt: V září letošního roku si připomínáme 100. výročí narození jednoho z nejslavnějších a nejpřekládanějších polských autorů - Stanisława Lema (1921-2006). Toto nedožité jubileum je pro nás př́ležitostí ke krátkému zamyšlení nad pozoruhodně pestrou a různorodou podobou jeho díla. Nejprve se pokusíme o stručnou obecnější charakteristiku Lemovy tvorby, abychom se následně zaměřili na jeden z jeho zajímavých teoretických textů. Vyslovením svérázné evoluční hypotézy zde Lem reagoval na pandemickou situaci, s níž je lidstvo konfrontováno od 80. let minulého století - nákazu virem HIV.
\end{abstract}

Klíčová slova: science fiction; filosofie; evoluce; virus; HIV

\section{THE UNIVERSE, HUMAN BEINGS AND VIRUSES (STANISLAW LEM)}

Abstract: September this year marks the 100th birth anniversary of one of Poland's most famous and most translated authors - Stanisław Lem (1921-2006). This jubilee is a great opportunity for us to think briefly about all the eclectic and miscellaneous form of this work. First, we will try to make a brief, general description of Lem's work, so that we can then focus on one of his interesting theoretical texts. In this essay, Lem responded by expressing a peculiar evolutionary hypothesis to the pandemic situation that mankind has been confronted with since the 1980s - HIV infection.

Key words: science-fiction; philosophy; evolution; virus; HIV

Letošní 100. výročí narození Stanisława Lema je příležitostí k zamyšlení nad jeho dílem, v němž se zcela originálním způsobem spojila umělecká a teoretická tvorba. V našem krátkém připomenutí různorodosti pozoruhodného Lemova myšlenkového světa můžeme vyjít z hodnocení inspirací, které mu poskytla science fiction. Literární forma je totiž také jednou z významných cest k rozvíjení lidského rozměru filosofického sdělení.

\section{Od science-fiction $k$ filosofii}

Stanisław Lem bývá nejčastěji spojován se science fiction, jeho autorský záběr však byl daleko širší (Weigel 1995) a zahrnuje i pozoruhodně tematicky pestrou oblast teoretického myšlení. Lem usiloval o hlubší promýšlení motivů a otázek, které nejprve přijala za své právě science fiction. 
Připomeňme zde proto nejprve Lemovy literární počátky v tomto žánru. Po H. G. Wellsem inspirované novele Mart’an zaznamenal daleko výraznější úspěch Lemův další román - Astronauti (1951). Toto dnes již klasické dílo ${ }^{1}$ budovatelské etapy sci-fi tvorby východního bloku je obrazem mírové mezinárodní spolupráce v nepř́lišs vzdálené (komunistické) budoucnosti i varováním před důsledky války. Pro nás dnes je především svědectvím o futuristických představách poznamenaných dobovou atmosférou. Podle nich lidstvo bude neomezeně přetvářet svět a uskutečňovat velké projekty. V Lemově románu jsou nap̌r. zažehnuta ,atomová Slunce“ k rozpouštění polárního zalednění, aby získanou vodu využívaly obří hydroelektrárny. Tento konkrétní př́íklad zde uvádíme pro zajímavost z toho důvodu, že stejný nápad nalezneme o několik let dř́ve v práci slovenského filosofa A. Siráckeho (Sirácky 1946, 128).

Další Lemův autorský vývoj reflektoval nejen technologický vývoj, ale také s ním spojená závažná filosofickoantropologická a axiologická témata (Solaris). Mnohé Lemovy texty jsou však pozoruhodné i tím, že obsahují originální humorný nadhled (Bajky robotů, Kyberiáda). Jen nemnoho autorů sci-fi (např. Calvino, Adams, bratři Strugačtí, Bulyčov) se takto dokázalo nebrat př́liš vážně. ${ }^{2}$ Tento aspekt tvorby Lem rozvinul až do borgesovské podoby recenzí na neexistující knihy (Dokonalá prázdnota).

Lem ovšem nebyl jen autorem science fiction, ale stal se i jejím náročným kritikem. Považoval totiž značnou část této literatury za povrchní, nedostatečně promyšlenou a v posledku zbytečnou prvoplánovou zábavu bez hlubšího smyslu. Lemův pohled se značně podobá skeptickému hodnocení M. Butora (Butor 1969, 19-27) a shoduje se s ním i v přesvědčení o neoddělitelnosti tvorby a kritiky jako důležitého nástroje autorské sebereflexe. Kritickému hodnocení „neohraničeného literárního vesmíru“ je věnována např. Lemova dvoudílná monografie Fantastyka i futurologia (Lem 1970, 6). Nalezneme však i ironické desatero rad, jak se vyhnout četbě špatné sci-fi (Weigel 1995, 101-103).

Význam kritického př́stupu pro Lemovu tvorbu můžeme doložit odkazem na filosofické stránky jeho díla. Science fiction otevřela fascinující možnosti nových témat i reflexí témat tradičních v nových perspektivách. Lidské místo ve vesmíru, problém možností a mezí vzájemného porozumění inteligentních bytostí, technologický rozvoj a jeho dopady na tradiční hodnoty jsou nepochybně závažnými filosofickými a etickými problémy. Lem se ve svém filosofickém debutu formou platonského dialogu pokusil o jistou sumarizaci mnoha pozoruhodných otázek (Lem 1957). Již samotný předlouhý a provokativní název textu je jejich výčtem - a vyvolává nutně oprávněný dojem poněkud eklektické autorovy nevyhraněnosti. Tu ovšem Lem posléze překonal a podněty z oblasti vědy a techniky se pro něj staly východiskem trvalého zájmu o zkoumání problému bytí a vývoje přirozených a umělých struktur (viz např. Summa technologiae).

Literární kritiku jako zdroj obecnějších závěrů Lem využil v pozoruhodné práci Filosofie náhody (1968). Také zde je předmětem zkoumání onen „papírový vesmír“ literárních děl. Klíčem k reflexi kategorie nahodilosti je analýza literárního textu jako struktury nadané svébytným vývojem a životem: „... čím je v biocenóze jeden druh, tím je v kultuře - literatura“ (Lem 1988, 25). V této souvislosti můžeme navíc upozornit, že ontologické a evoluční závěry této analogie také tvoří zvláštní tematickou i dobovou paralelu s klíčovou prací Monodovou (Monod, 1970). Dodejme ještě, že ve stejné době se také etablovala relativně nová oblast teoretického myšlení,

\footnotetext{
${ }^{1}$ Kniha se dočkala i zfilmování pod názvem Mlčící hvězda (1959).

${ }^{2}$ Ostatně i v reálném životě S. Lema najdeme groteskní moment - paranoidní obvinění jiného slavného autora sci-fi P. K. Dicka adresované FBI. Dick zpochybnil Lemovu reálnou existenci a formuloval udání, že za fiktivní osobou se skrývá komunistické spiknutí.
} 
která sumarizovala do té doby na různé úrovni řešenou problematiku řady disciplín - bioetika. Je nepochybné, že právě bioetické otázky tvoří významnou inspiraci také pro science fiction. My se zde zaměříme na jeden z Lemových pozdějších teoretických textů, kde se propojuje bioetická a evoluční perspektiva s otázkou role nahodilosti. Lem v tomto textu reagoval na závažnou hrozbu, s níž je lidstvo konfrontováno od 80. let minulého století.

\section{Viry a evoluce}

Předmětem našeho zájmu nyní bude Lemův esejistický text, který rozpracovává originálním způsobem evoluční problematiku. Aniž bychom chtěli nadměrně podlehnout svůdným aktualizacím v souvislosti se soudobou pandemií, pokusíme se přiblížit Lemovu hypotézu o evolučních souvislostech jiného závažného původce onemocnění - viru HIV. I přes dnes intenzivně prožívanou koronavirovou krizi je totiž právě onemocnění AIDS přetrvávajícím celosvětovým epidemickým problémem nejzávažnějším.

V roce 1989 publikoval S. Lem v polském časopise Wiedza $i$ žycie text, který později převzal i náš časopis Vesmir (Lem 1989, 1991). Tento text vychází z necelého desetiletí probíhajícího výzkumu viru HIV. Infekce AIDS začala být vnímána jako dosud skrytý globální problém na počátku 80 . let.

Stanislaw Lem ve své analýze přibližuje čtenáři dobovou úroveň znalostí o fungování virů jakožto vnitrobuněčných parazitů. Současně upozorňuje na specifičnost adaptační strategie viru HIV. V této souvislosti Lem formuloval i zmíněnou evoluční hypotézu.

Lem nejprve podává výklad charakteristiky a specifik virů. Obecně platí, že jakýkoliv parazitický biologický druh v průběhu své evoluce vytváŕí vybalancovanou rovnováhu se svým konkrétním hostitelem. Je to zapříčiněno tím, že - poněkud metaforicky řečeno - není v zájmu parazita zahubit svého hostitele. Viry jsou vnitrobuněční parazité neschopní samostatné aktivní existence. Působí tak, že po infikování hostitelské buňky ji donutí k produkci svých kopií, což je podstatou virových onemocnění. Virus HIV však patří ke specifické skupině virů, které napadají a potlačují imunitní systém hostitele. Ten se následně nedokáže účinně bránit jiným infekčním atakům. Znamená to tedy, že organismus neumírá na specifickou nemoc vyvolanou samotným virem HIV: „Tento virus dosáhl vysoké adaptační efektivnosti, založené na strategii nového typu: nezpůsobuje konkrétní chorobu, ale zbavuje organismus ochrany před jakoukoliv chorobou.“" (Lem 1991, 647) Problémem však je, že infikování tímto typem viru se relativně dlouhou dobu nemusí klinicky projevovat. Toto dlouhé latentní stádium poskytuje dostatek času k šíření virové nákazy v populaci. Dalším problémovým aspektem je i vysoká mutabilita tohoto viru. Nahodile vznikající variabilita je příčinou obtíží při vytváření vhodné vakcíny (obdobně je tomu ovšem i u viru rýmy či chřipky). Ani po čtyřech dekádách intenzivního výzkumu se tak dosud nepodařilo efektivní vakcínu proti viru HIV vytvořit. To dnes přitakává Lemově skepsi vůči dobovým optimistickým prognózám (Lem 1991, 649).

K charakteristikám infekce HIV patř́ i to, jakým způsobem se nákaza ve většině prrípadů přenáší. Vazba na oblast lidské sexuality znamená v podmínkách soudobé globální civilizace a moderního životního stylu to, že se „... mění nakonec skoro celý svět ve vhodné prostředí pro existenci a širření viru.“ (Lem 1991, 647) Možnosti prevence narážejí jednak na samu biologickou podstatu lidské existence, jednak na zásadní konflikty v oblasti lidských práv (práva menšin, nemožnost vynucení doživotní karantény u nakažených atd.). 
Tyto otázky jsou samozřejmě v dnešní době známy a představují významnou oblast bioetického i politického diskurzu. Proto není naším cílem se jimi nyní na tomto místě zabývat. Chceme zde především přiblížit Lemův pozoruhodný myšlenkový svět, a proto se zaměříme na zajímavou hypotézu, kterou v uvedeném textu autor formuloval.

Lem totiž zpochybnil poměrně rozšířený názor, že virus HIV realizuje zcela novou evoluční strategii. Nabídl otázku, zda obdobný typ viru již v historii pozemské živé přírody evolučně neintervenoval. A jako hypotetickou odpověd' dal do souvislosti možný výskyt obdobného viru (včetně jeho vazby na oblast sexuální reprodukce hostitele) a vznik skupiny organismů, jakou je sociální hmyz. Jeho vysvětlení je založeno na představě, že tento typ organismů v procesu evoluce vytvořil zcela specifickou ochranu před šířením sexuálně přenosné nákazy - cestou minimalizace sexuálních aktivit. Naprostá většina členů populace mravenců, vos, včel či termitů je totiž bezpohlavní a reprodukci celé kolonie zajišt'uje jedna matka. Lem nabízí možné evoluční vysvětlení dávným kontaktem s virem obdobným viru HIV. Tento kontakt hypoteticky vyústil v uvedenou adaptaci, zatímco „... dvoupohlavní sociálně žijící prahmyz vyhynul.“ (Lem 1991, 648)

Uvedená Lemova hypotéza je nesporně zajímavá, zatím však nebyly nalezeny podpůrné důkazy ve fosilních záznamech. Ostatně i sám Lem upozornil na problematičnost vytváření svůdných hypotéz v oblasti evolučních úvah. $\mathrm{K}$ dalšímu možnému tématu $\mathrm{z}$ této oblasti se proto vyjádřil velmi opatrně: „I proto se nepokouším nazvat gigantickou záhubu dinosaurů před 45 milióny let virovou pandemií. Mimo jiné proto, že existuje mnoho druhů virů zaměřených na odlišné hostitele a je riskantní postulovat takovou prríbuznost všech vymřelých ještěrů, která by umožnila jejich vyhubení jedinou skupinou virů. Navíc nás dějiny vědy učí, že hypotézy, které stručně a jasně vysvětlují všechno, nevysvětlují v podstatě nic.“ (Lem 1991, 649) Proto i my raději považujme uvedené evoluční extrapolace především za důkaz Lemovy mimořádné schopnosti tvůrčího myšlení, které dokázalo originálním způsobem zpř́ístupňovat aktuální vědecká témata ne pouze ve volném rámci fantazie umělecké literární tvorby.

Použitý krátký esejistický Lemův text nám však může poskytnout i podněty v souvislosti s dnešní pandemickou krizí vyvolanou virem SARS-CoV-2. Již jsme uvedli, že Lem s obavou upozornil na to, že virus HIV nalezl optimální podmínky pro své šíření v globální civilizaci na sklonku minulého století. A poznamenal, že pokud by se obdobný typ viru objevil v minulosti (v pravěku), jeho šíření by se omezilo na lokální lidskou populaci. Tu by infekce vyhubila a tím by se její šíření zastavilo. (Lem 1991, 648) A tu je docela zajímavou dnešní paralelou týkající se koronavirové pandemie diskutovaná hypotéza (podložená evolučně genomickým výzkumem) o masivní pravěké epidemii obdobného typu viru ve východní Asii (Souilmi et al. 2021).

Nakonec uved'me ještě jednu poznámku obsaženou v Lemově eseji. I ona má nezamýšlenou vazbu právě na naši dnešní situaci, i když se týká oné starší hrozby - onemocnění AIDS. Lem zde píše, že při diskusi o viru HIV zaznělo i to, že ,... pokud se tento vir naučí létat, budeme všichni potřebovat masky.“ (Lem 1991, 649) A tak jen závěrem dodejme, že Lemova tvorba literární i jeho teoretické úvahy o lidské budoucnosti světlé či naopak temné dokázaly čtenářům přiblížit i hrozby, které před námi dnes stojí v podobě či kontextech globálních problémů jako důsledků expanze naší civilizace a našeho života v jejím rámci. 


\section{Bibliografie}

Butor, M. (1969): Repertoár, Odeon.

Lem, S. (1957): Dialogi o zmartwychwstaniu atomowym, teorii niemożności, filozoficznych korzyściach ludożerstwa, smutku w probówce, psychoanalizie cybernetycznej, elektrycznej metempsychozie, sprzężeniach zwrotnych ewolucji, eschatologii cybernetycznej, osobowości sieci elektrycznych, przewrotności elektromózgów, życiu wiecznym w skrzyni, konstruowaniu geniuszów, epilepsji kapitalizmu, maszynach do rzadzenia, projektowaniu systemów społecznych, Wydawnictwo literackie.

Lem, S. (1970): Fantastyka i futurologia I, II, Wydawnictvo literackie.

Lem, S. (1988): Filozofia przypadku (3., přeprac.vyd.), Wydawnictvo literackie.

Lem, S. (1991): Strategie parazitů, virus HIV a jedna evoluční hypotéza, Vesmír 70(11), 646649.

Lem, S. (1989): Strategie pasožytów, wirus AIDS i osobliwa hypoteza ewolucyjna, Wiedza $i$ žycie 11/12, 32-38.

Monod, J. (1970): Le hasard et la nécessité: essai sur la philosophie naturelle de la biologie moderne, Éditions de Seuil.

Sirácky, A. (1946): Umierajúca civilizácia. Na prelome vekov, Matica slovenská.

Souilmi et al. (2021): An ancient viral epidemic involving host coronavirus interacting genes more than 20,000 years ago in East Asia, Current Biology [online] 31(16), dostupné z: < https://doi.org/10.1016/j.cub.2021.05.067 >.

Weigel, P. (1995): Stanisław Lem - životopis, Magnet-Press.

Toto dílo lze užít v souladu s licenčními podmínkami Creative Commons BY-NC-ND 4.0 International (https://creativecommons.org/licenses/by-nc-nd/4.0/legalcode). Uvedené se nevztahuje na díla či prvky (např. obrazovou či fotografickou dokumentaci), které jsou v díle užity na základě smluvní licence nebo výjimky či omezení př́slušných práv. 